\title{
Global transcriptional analysis of acid-inducible genes in Streptococcus mutans: multiple two- component systems involved in acid adaptation
}

Correspondence
Yung-Hua Li
yung-hua.li@dal.ca

Received 10 June 2009

Revised 7 July 2009

Accepted 13 July 2009

\author{
Yongxing Gong, ${ }^{1} \dagger$ Xiao-Lin Tian, ${ }^{1} \dagger$ Tara Sutherland, ${ }^{1}$ Gary Sisson, ${ }^{2}$ \\ Junni Mai, ${ }^{1,3}$ Junqi Ling ${ }^{3}$ and Yung-Hua Li ${ }^{1,2}$ \\ ${ }^{1}$ Department of Applied Oral Sciences, Dalhousie University, Halifax, Canada \\ ${ }^{2}$ Department of Microbiology and Immunology, Dalhousie University, Halifax, Canada \\ ${ }^{3}$ Guanghua School of Stomatology, Sun Yat-Sen University, Guangzhou, PR China
}

\begin{abstract}
Streptococcus mutans in dental biofilms is regularly exposed to cycles of acidic $\mathrm{pH}$ during the ingestion of fermentable dietary carbohydrates. The ability of $S$. mutans to tolerate low $\mathrm{pH}$ is crucial for its virulence and pathogenesis in dental caries. To better understand its acid tolerance mechanisms, we performed genome-wide transcriptional analysis of $S$. mutans in response to an acidic $\mathrm{pH}$ signal. The preliminary results showed that adaptation of $S$. mutans to $\mathrm{pH} 5.5$ induced differential expression of nearly $14 \%$ of the genes in the genome, including 169 upregulated genes and 108 downregulated genes, largely categorized into nine functional groups. One of the most interesting findings was that the genes encoding multiple two-component systems (TCSs), including CiaHR, LevSR, LiaSR, ScnKR, Hk/Rr1037/1038 and ComDE, were upregulated during acid adaptation. Real-time qRT-PCR confirmed the same trend in the expression profiles of these genes at $\mathrm{pH}$ 5.5. To determine the roles of these transduction systems in acid adaptation, mutants with a deletion of the histidine-kinase-encoding genes were constructed and assayed for the acid tolerance response (ATR). The results revealed that inactivation of each of these systems resulted in a mutant that was impaired in ATR, since pre-exposure of these mutants to $\mathrm{pH} 5.5 \mathrm{did}$ not induce the same level of protection against lethal $\mathrm{pH}$ levels as the parent did. A competitive fitness assay showed that all the mutants were unable to compete with the parent strain for persistence in dual-strain mixed cultures at acidic $\mathrm{pH}$, although, with the exception of the mutant in liaS, little effect was observed at neutral $\mathrm{pH}$. The evidence from this study suggests that the multiple TCSs are required for $S$. mutans to orchestrate its signal transduction networks for optimal adaptation to acidic $\mathrm{pH}$.
\end{abstract}

\section{INTRODUCTION}

The human oral cavity is a highly dynamic environment that undergoes rapid and often substantial changes in nutrient availability, nutrient type, $\mathrm{pH}$, oxygen tension and interbacterial interactions involving either competition or cooperation (Burne et al., 1999; Kuramitsu et al., 2007; Lemos et al., 2005; Marsh, 1994). Bacteria, such as

†These authors contributed equally to this work.

Abbreviations: ATR, acid tolerance response; $\mathrm{Cl}$, competitive index; CSP, competence signalling peptide; TCS, two-component system.

The NCBI GEO (www.ncbi.nlm.nih.gov/geo) accession number for the microarray data reported in this paper is GSE15125.

A figure describing the strategy for construction and confirmation of gene deletion mutants by PCR ligation mutagenesis, and tables of primers used for qRT-PCR and construction of the mutants in this study, and of genes differentially expressed in $S$. mutans during acid adaptation are available with the online version of this paper. streptococci, living in dental biofilms are frequently exposed to cycles of such environmental challenges (Burne et al., 1999; Lemos et al., 2005). During intake of sweetened foodstuff, for example, carbohydrate concentrations in the oral cavity can rapidly increase from around $10 \mu \mathrm{m}$ to well over $10 \mathrm{mM}$ (Lemos et al., 2005; Lemos \& Burne, 2008). Concurrent with the influx of dietary carbohydrates is a dramatic decrease in $\mathrm{pH}$ to values of 4 or lower in dental biofilms (Quivey et al., 2001). This socalled 'feast-and-famine' lifestyle provides some organisms, such as Streptococcus mutans, with a significant advantage in competition with other species in dental biofilms, resulting in an emergence of numerically significant members in dental plaque that may cause caries (Marsh, 1994). These environmental variations are known to have profound impacts on bacterial gene expression and have been unequivocally shown to be the factors that influence the microbial composition and biological activities of 
dental plaque biofilms (Lemos et al., 2005; Marsh, 1994; Quivey et al., 2001). To persist in dental biofilms, oral bacteria must be able to sense, respond and adapt to such rapid and unexpected environmental changes.

S. mutans is a Gram-positive bacterium that depends on a 'biofilm life-style' for survival and persistence in its natural ecosystem, dental plaque (Burne et al., 1999). Upon ingestion of dietary fermentable carbohydrates, S. mutans can rapidly produce acids and lower the plaque $\mathrm{pH}$, initiating the demineralization of the tooth surface. $S$. mutans is therefore considered as a primary aetiological agent of dental caries (Ajdic et al., 2002). The ability of $S$. mutans to produce and tolerate acids is crucial to its virulence and cariogenicity (Quivey et al., 2001; Li et al., 2008). Acid tolerance by $S$. mutans has been studied in some detail. It is well known that this organism can grow and carry out glycolysis at $\mathrm{pH}$ values below 5.0 and can drive the $\mathrm{pH}$ to values well below 4.0 (Quivey et al., 2001). The aciduricity of this organism has been attributed largely to the proton-extruding $\mathrm{F}_{1} \mathrm{~F}_{0}$-ATPase that functions well at $\mathrm{pH} 5.0$ and below, allowing the organism to maintain adequate $\Delta \mathrm{pH}$ when the external $\mathrm{pH}$ falls to 4.0 and lower (Bender et al., 1986; Cotter \& Hill, 2003). Other mechanisms of acid resistance in S. mutans include induction of stress proteins (Hamilton \& Svensäter, 1998; Len et al., 2004; Svensäter et al., 1997; Wilkins et al., 2002), changes in membrane-associated proteins and fatty acid composition (Fozo et al., 2007; Hasona et al., 2007), DNA repair enzymes (Hahn et al., 1999; Hanna et al., 2001) and increase in alkali production through several metabolic pathways (Burne et al., 1999; Griswold et al., 2006). Moreover, the ComCDE quorum-sensing system has been found to play a role in cell-density-dependent acid tolerance by S. mutans (Li et al., 2001b). S. mutans is also capable of mounting an adaptive acid tolerance response (ATR), since pre-exposure of S. mutans to pH 5.0-6.0 for 1-2 $\mathrm{h}$ (adaptation) renders the organism less susceptible to lethal acidification, as opposed to a quick $\mathrm{pH}$ drop by adding $\mathrm{HCl}$ to growing cultures (Nascimento et al., 2004;
Svensäter et al., 1997). This pH-inducible ATR has been well characterized in a number of bacteria, in which a signal $\mathrm{pH}$ that results in a sublethal effect on the cells for sufficient time appears to be important for induction of ATR (Cotter \& Hill, 2003; Foster, 1995). However, unlike other bacteria, such as Bacillus subtilis and Escherichia coli that often use alternative sigma factors to coordinate their gene expression in response to environmental stresses (Haldenwang, 1995; Helmann, 2002), the S. mutans genome contains only two sigma factors, $\sigma^{70}$ and $\sigma^{\mathrm{X}}$, and their roles in regulating acid tolerance are unclear (Ajdic et al., 2002; Lemos \& Burne, 2008; Quivey et al., 2001). How S. mutans senses and integrates $\mathrm{pH}$ signals for acid adaptation remains unknown. In this study, we provide the evidence that multiple two-component systems (TCS) are involved in acid adaptation by $S$. mutans. The results from this study provide new insights into the molecular mechanisms by which $S$. mutans senses and adapts to acidic $\mathrm{pH}$ in dental biofilms.

\section{METHODS}

Bacterial strains, media and growth conditions. All strains used in this study and their relevant characteristics are listed in Table 1. S. mutans wild-type strains were grown on Todd-Hewitt (3\%) medium plus $0.3 \%$ yeast extract (THYE), while the mutants were maintained on THYE containing $10 \mu \mathrm{g}$ erythromycin $\mathrm{ml}^{-1}$. The medium used for acid adaptation and RNA isolation was TYG (tryptone, 3\%; yeast extract, $0.3 \%$; glucose, $20 \mathrm{mM}$ ) at a desirable $\mathrm{pH}$ buffered with $40 \mathrm{mM}$ potassium phosphate/citric acid. The strains were grown at $37{ }^{\circ} \mathrm{C}$ in an incubator with an atmosphere of $5 \% \mathrm{CO}_{2}$.

Acid adaptation and RNA isolation. To identify acid-inducible genes, we grew exponential-phase cells of S. mutans UA159 for $2 \mathrm{~h}$ in TYG broth at $\mathrm{pH} 5.5$, a signal $\mathrm{pH}$ that has been demonstrated to induce acid adaptation of S. mutans effectively (Li et al., 2001b; Svensäter et al., 1997); cells grown at $\mathrm{pH} 7.5$ were used as a control. Following acid adaptation, the cell pellets were collected by centrifugation at $8000 \mathrm{~g}$ for $15 \mathrm{~min}$ at $4{ }^{\circ} \mathrm{C}$ and resuspended in $1 \mathrm{ml}$ cool Trizol (Invitrogen). Total RNA was extracted by a FastPrep method as described by Hanna et al. (2001). The extracted RNAs were precipitated with ethanol and resuspended in diethyl pyrocarbon-

Table 1. Bacterial strains and plasmids used in this study

\begin{tabular}{|c|c|c|}
\hline Strain/plasmid & Relevant characteristics & Source or reference \\
\hline \multicolumn{3}{|l|}{ S. mutans } \\
\hline UA159 & Wild-type, Erm ${ }^{\mathrm{s}}$ & Ajdic et al. (2002) \\
\hline NG8 & Wild-type, Erm ${ }^{\mathrm{s}}$ & Li et al. (2001a) \\
\hline SmciaH & UA159 $\Delta c i a H::$ erm, $\operatorname{Erm}^{\mathrm{r}}$ & This study \\
\hline SmlevS & UA159 $\Delta l e v S::$ erm, $\operatorname{Erm}^{\mathrm{r}}$ & This study \\
\hline SmliaS & UA159 $\Delta l i a S:$ erm, Erm $^{\mathrm{r}}$ & This study \\
\hline SmscnK & UA159 $\Delta s c n K::$ erm, Erm $^{r}$ & This study \\
\hline Smhk1037 & UA159 $\Delta h k 1037::$ erm, $\operatorname{Erm}^{\mathrm{r}}$ & This study \\
\hline \multicolumn{3}{|l|}{ Amplicon } \\
\hline Erm & erm cassette ( 860 bp) & This study \\
\hline \multicolumn{3}{|l|}{ Plasmid } \\
\hline pVA-gtfA & pVA891 harbouring the S. mutans gtfA gene, $\mathrm{Erm}^{\mathrm{r}}$ & Li et al. (2001a) \\
\hline
\end{tabular}


treated (DEPC) water. The RNA was treated with RNase-free DNase I to remove genomic DNA and purified by passing through Qiagen RNeasy mini columns (Qiagen). Purified RNA was dissolved in $20 \mu \mathrm{l}$ RNase-free water and stored at $-80{ }^{\circ} \mathrm{C}$ until required for cDNA labelling. The concentration and quality of RNA samples were confirmed by spectrophotometer and gel electrophoresis.

cDNA synthesis, dye coupling and array hybridization. An indirect labelling method using SuperScript plus indirect cDNA labelling kit (Invitrogen) was used to make labelled cDNA probes. The labelling process included two steps: the first step involved the synthesis of first-strand cDNA with aminoallyl-dUTP in a reverse transcription reaction; and the second step involved labelling of aminoallyl-modified cDNA with AlexaFluor 555 (green) or AlexaFluor 647 (red). The labelled cDNA probes were purified and assessed for dye coupling efficiency and concentration using the procedures recommended by the manufacturer (Invitrogen). The labelled probes were then used for array hybridization or stored at $-20{ }^{\circ} \mathrm{C}$ until required.

S. mutans microarray slides used in this study were obtained from the Pathogen Functional Genomics Resource Center (PFGRC) at the J. Craig Venter Institute. Each array slide consisted of 1948 70-mer oligonucleotides representing $99 \%$ of the ORFs of the S. mutans UA159 genome. Array hybridization was conducted using a PFGRC protocol (http://pfgrc.tigr.org/protocols.shtml) with minor modification. After hybridization, the microarray slides were subjected to a series of washings in a buffer of $1 \times$ SSC plus $0.1 \%$ SDS, dried in high-pressure air and scanned by a ScanArray 5000XL Reader (Perkin Elmer).

Array data analysis. After array slides were scanned, the resulting TIFF images were loaded into TIGR Spotfinder software (www.tigr. org/software/) and overlaid. A spot grid was created according to TIGR specifications and manually adjusted to fit all spots within the grid, and the intensity values of each spot were determined. Signal intensities of individual channels from an array slide were averaged and normalized using microarray data analysis software (MIDAS) by using LOWESS and iterative log mean centring with default settings, followed by in-slide replicate analysis. A $t$-test was used to determine the consistency of ratios or fold changes across replicate hybridizations. Only genes whose ratios were $\geqslant$ twofold changes (either increase or decrease) with $99 \%$ confidence $(P \leqslant 0.01)$ were considered statistically significant.

Real-time quantitative RT-PCR. To validate the microarray data, we performed real-time qRT-PCR to examine the expression of a subset of the differentially expressed genes identified by the microarray analysis. qRT-PCR was carried out using a Cepheid Smart Cycler System and the QuantiTech SYBR green PCR kit (Qiagen). All primers designed for qRT-PCR analysis are listed in Supplementary Table S1. The expression levels of target genes were normalized using the gyrA gene of S. mutans as an internal standard, since it produced little variation of expression (Ajdic \& Pham, 2007; Hasona et al., 2007). A standard curve was plotted with cycle threshold $\left(C_{\mathrm{T}}\right)$ values obtained from amplification of known quantities of cDNAs and also used to determine the efficiency of amplification. A non-template control was included to confirm the absence of primer dimer formation. Each assay was performed with RNA samples in triplicate, and fold changes of the expression levels were calculated by using the following equations: $\Delta C_{\mathrm{T}}=C_{\mathrm{T}}$ (target gene) $-C_{\mathrm{T}}(g y r A) ; \Delta \Delta C_{\mathrm{T}}=\Delta C_{\mathrm{T}}$ (reference cDNA) $-\Delta C_{\mathrm{T}}$ (test cDNA), so that the fold (ratio) $=2^{-\Delta \Delta C_{\mathrm{T}}}$.

Construction of gene deletion mutants. To determine the effect of inactivation of each TCS on acid adaptation, we constructed gene deletion mutants defective in the histidine kinase sensor proteins in $S$. mutans UA159 by an allelic replacement strategy involving PCRligation mutagenesis as described by Lau et al. (2002). All the primers used to construct and confirm these mutants are presented in Supplementary Table S1. To construct the ciaH mutant, for example, an $821 \mathrm{bp}$ fragment $5^{\prime}$ from the ciaH start codon (ciaH-up) was amplified from $S$. mutans UA159 genomic DNA by using primers ciaH-P1 and ciaH-P2 (containing an AscI site at its $5^{\prime}$ end). Another amplicon, designated ciaH-dw, was $625 \mathrm{bp} 3^{\prime}$ from ciaH and was amplified with ciaH-P3 (with an FseI site at the 5' end) and ciaH-P4 primers. An 860 bp erythromycin resistance cassette (Em-860) was amplified from a mutant (Li et al., 2002) by using primers Em-P1 and Em-P2. These amplicons were digested, purified and ligated to produce a ciaH-up ::Em::ciaH-dw fragment. The ligation product was directly used to transform S. mutans UA159. Following doublecrossover recombination, the internal region of the ciaH gene was completely replaced by the erythromycin cassette. The newly constructed mutants were genetically confirmed by a PCR strategy and sequencing (Supplementary Fig. S1). The same strategy was used to construct and confirm the rest of the mutants. The confirmed mutants were named SmciaH ( $\Delta c i a H:: E m)$, SmlevS ( $\Delta l e v S:: E m)$,

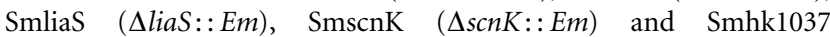
$(\Delta h k 1037:: E m)$. All the mutants were then assayed for their growth at $\mathrm{pH} 7.5$ and 5.5. Their growth curves were obtained by $\mathrm{OD}_{600}$ readings using a spectrophotometer.

Assay for ATR. To determine the effect of inactivation of the histidine kinase sensor protein on acid adaptation by $S$. mutans, all the mutants and the parent were assayed for their survival at $\mathrm{pH} 3.5$ with or without pre-exposure to $\mathrm{pH} 5.5$ for $2 \mathrm{~h}$ using a protocol described by Li et al. (2001b). Briefly, exponential-phase cells of each strain were divided into two groups: one resuspended in fresh TYG broth at pH 5.5 and another resuspended in TYG broth at pH 7.5. The cultures were grown at $37{ }^{\circ} \mathrm{C}$ for $2 \mathrm{~h}$ and the cell pellets were collected by centrifugation at $8000 \mathrm{~g}$ for $15 \mathrm{~min}$. Both adapted $(\mathrm{pH} 5.5)$ and non-adapted cells ( $\mathrm{pH} 7.5)$ were immediately resuspended in $5 \mathrm{ml}$ fresh TYG (pH 3.5) at a cell density of 0.6 at $\mathrm{OD}_{600}$. The cultures were incubated at $37{ }^{\circ} \mathrm{C}$ for $2 \mathrm{~h}$ and an aliquot of cell suspension was taken from each sample to assay viable cell counts. All the samples were serially diluted in $10 \mathrm{mM}$ potassium phosphate buffer ( $\mathrm{pH}$ 7.2) and plated on THYE agar plates. The numbers of surviving cells were determined by viable cell counts after the plates were incubated at $37{ }^{\circ} \mathrm{C}$ for 2 days. The percentage survival was calculated from the numbers of viable surviving cells and total viable counts at time zero. All samples were taken in duplicate from two independent experiments.

Glycolytic pH drop assay. A glycolytic $\mathrm{pH}$ drop assay was conducted to determine acid production by the mutants using the method described by Li et al. (2008). Briefly, stationary-phase cells (overnight culture) were harvested and resuspended in a salt solution ( $50 \mathrm{mM} \mathrm{KCl}$ and $1 \mathrm{mM} \mathrm{MgCl}_{2}$ ) to a final cell density of 1.0 at $\mathrm{OD}_{600}$. The cell suspensions were adjusted to $\mathrm{pH} 7.5$ and glucose was then added to a final concentration of $56 \mathrm{mM}$. Changes of $\mathrm{pH}$ dropping profile were recorded for $2 \mathrm{~h}$ using a digital $\mathrm{pH}$ meter (Fisher) at room temperature.

Competence assay. To determine the effect of acidic $\mathrm{pH}$ on competence development, we assayed genetic transformation of two naturally transformable strains, S. mutans UA159 and NG8, grown at pH 5.5 or 7.5 using a modified protocol (Syvitski et al., 2007). Briefly, a $1: 20$ diluted overnight culture was grown in THYE at $37{ }^{\circ} \mathrm{C}$ for $2 \mathrm{~h}$. When the culture reached early to mid-exponential phase, the cell suspension was transferred into fresh pre-warmed THYE broth $(1: 10$ dilution) in four test tubes, two at $\mathrm{pH} 7.5$ and two at $\mathrm{pH}$ 5.5. The cultures were incubated at $37{ }^{\circ} \mathrm{C}$ until the cell density of each culture reached 0.25 at $\mathrm{OD}_{600}$. An aliquot $\left(1 \mu \mathrm{g} \mathrm{ml}^{-1}\right)$ of competence signalling peptide (CSP) was added into one culture in each group. 
The cultures were incubated at $37{ }^{\circ} \mathrm{C}$ for 20 min and transforming DNA was added into each culture at a final concentration of $1 \mu \mathrm{g} \mathrm{ml}^{-1}$. The transforming DNA was an integration plasmid, pVAgtfA, harbouring a $2.4 \mathrm{~kb}$ fragment of the $S$. mutans $\mathrm{gtfA}$ gene and an erythromycin resistance marker. After incubation for an additional $2 \mathrm{~h}$, the cell suspension was taken from each culture, diluted and spread on THYE and THYE plus erythromycin $\left(10 \mu \mathrm{g} \mathrm{ml}^{-1}\right)$ plates to determine the numbers of transformants and total recipient cells, respectively. Transformation frequency was expressed as the number of transformants over the total number of recipient cells $(\mathrm{ml}$ (culture) $)^{-1}$.

Competitive fitness assay. To further determine the effects of inactivation of each TCS on acid adaptation, we established dualstrain mixed cultures in a chemostat for competitive fitness analysis of the mutants in terms of their ability to compete with the parent for persistence under acidic $\mathrm{pH}$ culture conditions. Dual-strain mixed cultures were initiated in the chemostat by inoculating a $1: 1$ ratio of a mutant and the parent UA159. The chemostat and its operation were previously described in detail ( $\mathrm{Li}$ et al., 2001a, b). The temperature in the chemostat was maintained at $37 \pm 0.2{ }^{\circ} \mathrm{C}$ by a temperature controller (model R-600F; Cole Parmer), while culture $\mathrm{pH}$ was controlled by a $\mathrm{pH}$ meter via a digital $\mathrm{pH}$ controller (NV Multiparameter Analyser R735; Consort). Four-times-diluted THYE medium plus $10 \mathrm{mM}$ glucose was used for continuous cultures. The steady-state culture of each pair of strains was first established in the chemostat at $\mathrm{pH} 7.5 \pm 0.2$ at dilution rate of $0.1 \mathrm{~h}^{-1}$. After sampling at $\mathrm{pH} 7.5$, the $\mathrm{pH}$ controller was disconnected to allow the culture $\mathrm{pH}$ to drop through glycolytic acid production. When the culture reached steady-state, samples were taken again to determine viable cell counts and the $\mathrm{pH}$ profile of the cultures was recorded. The mutants were distinguished from the parent by growth on THYE agar plates with or without the addition of erythromycin $\left(10 \mu \mathrm{g} \mathrm{ml}^{-1}\right)$. A competitive index (CI) analysis was performed by determining the ratio of a mutant population to the parent population in the output samples divided by the ratio of these two populations in the input samples. CI values were analysed by Student's $t$-test, with $P<0.05$ considered statistically significant.

\section{RESULTS AND DISCUSSION}

\section{Overview of the effects of signal pH on the transcriptome}

To gain an insight into the molecular basis of acid adaptation by $S$. mutans, we used DNA microarrays to analyse genome-wide transcriptional profiles of $S$. mutans during adaptation to $\mathrm{pH}$ 5.5. The microarray data revealed that approximately $14 \%$ of the genes in the S. mutans genome displayed differential expression with a $P$-value $\leqslant 0.01$ during acid adaptation (Supplementary Table S2). Notably, more genes $(n=169)$ were upregulated than downregulated $(n=108)$ in response to acidic $\mathrm{pH}$. To validate the microarray data, we used real-time qRT-PCR to further examine the expression of a subset of the genes $(n=26)$, including six genes of unknown function and three genes, levR, liaR and hk1037, that did not show selectable levels of expression in microarray analysis (Table 2 ). With the exclusion of these three genes, and $\operatorname{lev} S$ that showed a sevenfold higher QRT-PCR value than the microarray analysis, we were able to measure the correlation in the expression ratios of 22 genes between the microarray and qRT-PCR. The results showed a fairly good correlation $\left(r^{2}=0.67\right)$ in gene expression ratios between the two methods (Fig. 1). Despite some variations, the qRT-PCR results clearly revealed the same trend in the expression of all the genes tested, thus validating the microarray data.

\section{Upregulated genes}

The majority of upregulated genes were categorized into nine functional groups (Fig. 2), (i) transport and ATPbinding proteins $(n=28)$, (ii) energy metabolism $(n=14)$, (iii) cellular processes $(n=13)$, (iv) two-component signal transduction $(n=9)$, (v) transcriptional regulators $(n=15)$, (vi) cation and ion uptake and binding proteins $(n=6)$, (vii) biosynthesis of proteins, amino acids and co-factors $(n=9)$, (viii) metabolism of nucleic acids $(n=16)$, and (ix) unknown or unassigned hypothetical proteins $(n=48)$. Many encode ATP-dependent transporters, including Ftype, P-type and ABC-type ATPases (Supplementary Table S2). F-type ATPases that use an electrochemical gradient of $\mathrm{H}^{+}$or $\mathrm{Na}^{+}$to synthesize ATP, or hydrolyse ATP to reverse an electrochemical gradient, are known to play important roles in maintaining internal $\mathrm{pH}\left(\mathrm{pH}_{\mathrm{i}}\right)$ homeostasis (Cotter \& Hill, 2003; Quivey et al., 2001). For example, the protontranslocation $\mathrm{F}_{1} \mathrm{~F}_{0}-\mathrm{H} / \mathrm{ATP}$ ase operon in $\mathrm{S}$. mutans consists of eight genes, atpEBF and atpHAGDC, which respectively encode the $\mathrm{c}$, a and $\mathrm{b}$ subunits of the membrane-embedded $\mathrm{F}_{0}$ complex and the $\delta, \alpha, \gamma, \beta$, and $\varepsilon$ subunits of the peripherally bound $F_{1}$ protein (Kuhnert et al., 2004). The $\mathrm{F}_{0}$ complex has proton-translocating activity, while the $\mathrm{F}_{1}$ complex has ATPase activity. The $\mathrm{F}_{1} \mathrm{~F}_{0}$-ATPase largely contributes to the aciduricity of $S$. mutans, since it functions well below pH 5.0 and allows the organism to maintain an adequate $\Delta \mathrm{pH}$ when the external $\mathrm{pH}$ falls to 4.0 and lower (Bender et al., 1986; Quivey et al., 2001). Our microarray work revealed that all the genes from SMU.1527 to SMU.1534, encoding the eight subunits of the $\mathrm{F}_{1} \mathrm{~F}_{0}$-ATPase, were upregulated (2.3-3.8-fold) during acid adaptation. To confirm the array data, we used realtime qRT-PCR to assay the expression of two of the subunit-encoding genes, atpD and atpF, in the cells grown at $\mathrm{pH}$ 5.5. The results revealed that adaptation of $S$. mutans to $\mathrm{pH} 5.5$ indeed induced 2.26-3.87-fold increases in the expression of these genes (Table 2), thus validating the microarray data. Previous studies suggested that the $\mathrm{F}_{1} \mathrm{~F}_{0^{-}}$ ATPase in $S$. mutans might be constitutively expressed, since the promoter analysis of the $\mathrm{F}_{1} \mathrm{~F}_{0}$-ATPase operon showed a putative Pribnow box (TAAACT) and a clear -35 sequence of TTGACA, homologous with the canonical $\sigma^{70}$ promoter in E. coli, suggesting a housekeeping function for $\mathrm{F}_{1} \mathrm{~F}_{0}$-ATPase synthesis (Quivey et al., 2001). However, using transcriptional reporter gene fusions to the promoter of the atp operon, Quivey and colleagues found that the increase in $\mathrm{F}_{1} \mathrm{~F}_{0}-\mathrm{H} / \mathrm{ATPase}$ activity was correlated with increased transcription of the atp operon of $S$. mutans grown at low pH (Kuhnert et al., 2004). Using 2-DGE and mass spectroscopic analysis, Len et al. (2004) have found 
Table 2. A comparison of gene expression between microarray and qRT-PCR

Microarray fold changes were based on the means $(\geqslant$ or $\leqslant$ twofold with $P \leqslant 0.01$ ) of triplicate reactions. qRT-PCR values indicate fold changes in relative gene expression levels $\left(C_{\mathrm{T}}\right)$ of cells grown under two $\mathrm{pH}$ conditions. The fold differences $\left(\Delta C_{\mathrm{T}}\right)$ in expression levels of the genes tested were calculated from triplicate reactions against the $C_{\mathrm{T}}$ value of constitutively expressed gyrA of $S$. mutans UA159 using the equations described in the text. -, Not applicable.

\begin{tabular}{|c|c|c|c|c|}
\hline \multirow[t]{2}{*}{ Locus ID } & \multirow[t]{2}{*}{ Gene name } & \multirow[t]{2}{*}{ Functional description } & \multicolumn{2}{|c|}{ Fold difference (pH 5.5/7.5) } \\
\hline & & & Microarray & qRT-PCR \\
\hline \multicolumn{5}{|c|}{ Transporters } \\
\hline SMU.1528 & $\operatorname{atpD}$ & $\mathrm{F}_{0} \mathrm{~F}_{1}$ ATPase, beta subunit & 3.01 & 2.26 \\
\hline SMU.1532 & $\operatorname{atpF}$ & $\mathrm{F}_{0} \mathrm{~F}_{1}$ ATPase, $\mathrm{b}$ subunit & 3.23 & 3.87 \\
\hline SMU.1093 & vex3 & Putative $\mathrm{ABC}$ transporter & 6.74 & 3.48 \\
\hline \multicolumn{5}{|l|}{ TCS } \\
\hline SMU.1128 & $c i a H$ & Histidine kinase protein, $\mathrm{CiaH}$ & 2.19 & 3.46 \\
\hline SMU.1129 & $\operatorname{ciaR}$ & Response regulator, CiaR & 2.96 & 8.39 \\
\hline SMU.1964 & $\operatorname{levR}$ & Response regulator, LevR & - & 8.56 \\
\hline SMU.1965 & $\operatorname{lev} S$ & Histidine kinase protein, LevS & 2.74 & 18.2 \\
\hline SMU.486 & $\operatorname{liaS}$ & Histidine kinase protein, LiaS & 2.05 & 3.18 \\
\hline SMU.487 & liaR & Response regulator, LiaR & - & 4.25 \\
\hline SMU.1814 & $\operatorname{scnK}$ & Histidine kinase protein, Scnk & 2.15 & 2.74 \\
\hline SMU.1815 & $\operatorname{scn} R$ & Response regulator, $\mathrm{ScnR}$ & 2.05 & 2.68 \\
\hline SMU.1037 & $h k 1037$ & Histidine kinase protein, Hk1037 & - & 3.65 \\
\hline SMU.1038 & $\operatorname{rr} 1038$ & Response regulator, $\operatorname{Rr} 1038$ & 2.19 & 4.66 \\
\hline SMU.1916 & $\operatorname{comD}$ & Histidine kinase protein, ComD & 2.11 & 2.84 \\
\hline SMU.1917 & $\operatorname{com} E$ & Response regulator, ComE & 2.26 & 3.25 \\
\hline \multicolumn{5}{|c|}{ Competence } \\
\hline SMU.1997 & $\operatorname{com} X$ & Competence-specific sigma factor & 0.36 & 0.50 \\
\hline SMU.1987 & $\operatorname{com} Y A$ & Competence, DNA transport & 0.28 & 0.22 \\
\hline \multicolumn{5}{|c|}{ Bacteriocins } \\
\hline SMU.1913 & $i m m A$ & Putative immunity protein, Blp-like & 2.38 & 5.82 \\
\hline SMU.1914 & $n \operatorname{lm} C$ & Non-lantibiotic mutacin $\mathrm{V}$ & 2.92 & 7.07 \\
\hline \multicolumn{5}{|c|}{ Transcriptional factor } \\
\hline SMU.1805 & - & Transcriptional regulator & 3.20 & 5.04 \\
\hline \multicolumn{5}{|c|}{ Unknown function } \\
\hline SMU.239 & - & Hypothetical protein & 3.74 & 4.27 \\
\hline SMU.635 & - & Hypothetical protein & 4.13 & 5.96 \\
\hline SMU.1243 & - & Hypothetical protein & 5.87 & 3.65 \\
\hline SMU.673 & - & Hypothetical protein & 0.28 & 0.43 \\
\hline SMU.1642 & - & Hypothetical protein & 0.31 & 0.35 \\
\hline SMU.1803 & - & Hypothetical protein & 0.26 & 0.29 \\
\hline
\end{tabular}

that $\mathrm{pH} 5.0$ induces significantly higher levels of expression of at least two subunit proteins, $\alpha$ and $\varepsilon$, of the $\mathrm{F}_{1} \mathrm{~F}_{0}-\mathrm{H} /$ ATPase. Similar results have also been reported showing $\mathrm{pH}$-dependent increases in the transcription of the atp operon in both Streptococcus pneumoniae and Streptococcus bovis (Martin-Galiano et al., 2001). Clearly, the results from our study support the observations that acidic $\mathrm{pH}$ induces the expression of the genes encoding $\mathrm{F}_{1} \mathrm{~F}_{0}$-ATPase subunits at a transcriptional level in S. mutans.

In addition to F-type transporters, a large number of genes encoding P-type and ABC-type ATPase transporters were upregulated, including SMU.426 (copA), SMU.1563 ( $p a c L)$, SMU.2057 (cadA), SMU.1093/1094 (vex3/vex2), SMU.653 (tauC), SMU.879-882 ( $m s m F G K)$ and SMU.1412 (yhcA). The P-type ATPases are responsible for the transport of various inorganic ions, such as calcium, cadmium, copper and potassium (Kakinuma, 1998; Magalhaes et al., 2005). For instance, the copYAZ operon in $S$. mutans encodes a Ptype ATPase responsible for transport of copper, allowing this organism to tolerate the high concentrations of copper potentially released from dental amalgam (Vats \& Lee, 2001). pacL (SMU.1563), together with two other genes, SMU.1561 and SMU.1562, at the same locus, encodes a Ptype potassium transporter system. These genes, along with two other genes, SMU.1708 and SMU.1709, which also encode a putative potassium uptake system, were upregulated at $\mathrm{pH} 5.5$, suggesting that potassium might play an important role in regulating $\mathrm{pH}$ homeostasis during acid adaptation in S. mutans. Although little is known about potassium transport in acid adaptation of $S$. mutans, the mechanism involving $\mathrm{H}^{+}$extrusion/K $\mathrm{K}^{+}$influx through 


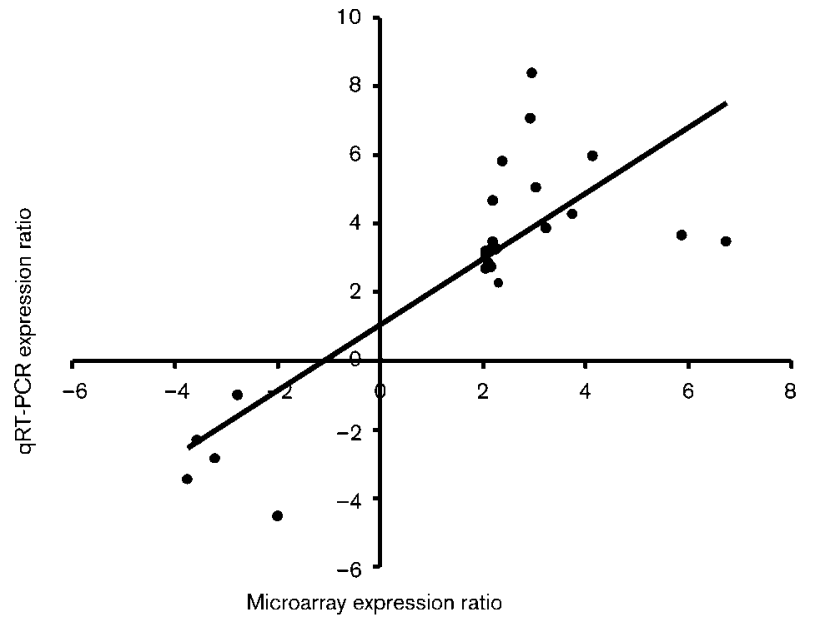

Fig. 1. Correlation of the expression ratios of 22 genes at $\mathrm{pH} 5.5$ versus 7.5 using data from microarray and real-time qRT-PCR. $r^{2}=0.67$.

$\mathrm{F}_{1} \mathrm{~F}_{0}$-ATPase and potassium uptake systems at acidic $\mathrm{pH}$ has been reported in E. coli and Enterococcus hirae (Kakinuma, 1998). ABC-type ATPases are the most abundant transporters in $S$. mutans and exhibit specificity for different substrates, amino acids, carbohydrates, oligopeptides, osmoprotectants (proline/glycine betaine, choline), inorganic ions, such as $\mathrm{Fe}^{3+}, \mathrm{Co}^{2+}, \mathrm{Mn}^{2+}$ and $\mathrm{Zn}^{2+}$, phosphate, nitrate, sulfate and molybdenum (Ajdic \& Pham, 2007; Cotter \& Hill, 2003; Kakinuma, 1998). These gene products may function to maintain cellular

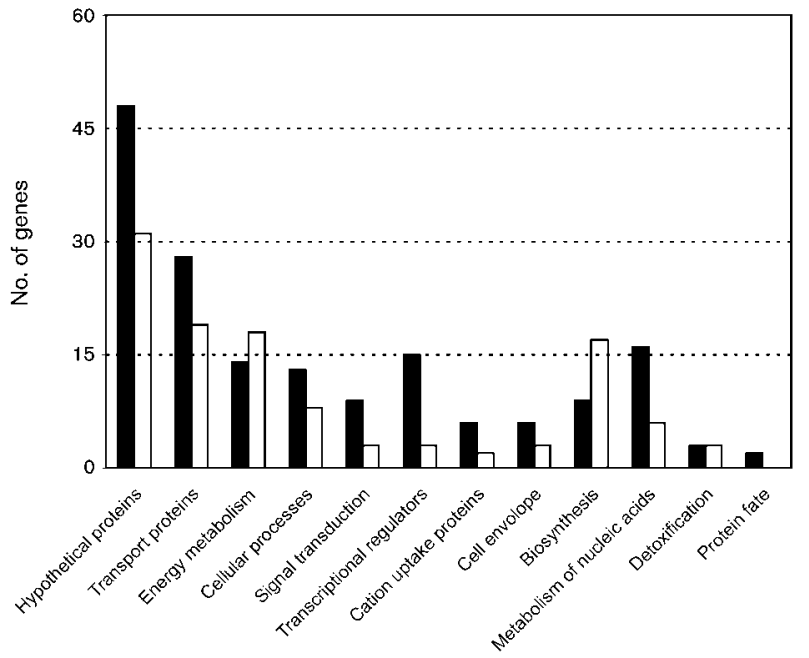

Fig. 2. The distribution of differentially expressed genes and their functional categories in S. mutans UA159 during acid adaptation. The genes were grouped according to the Los Alamos S. mutans genome database (www.oralgen.lanl.gov/). $\mathbf{\square}$, Upregulated genes; $\square$, downregulated genes. processes, metabolism and ion balance during acid adaptation. However, whether these gene products play direct roles in the ATR of $S$. mutans remains to be studied. Together, all three types of ATP-dependent ATPases may coordinately play their roles in the regulation and maintenance of cellular processes, ion balance and $\mathrm{pH}$ homeostasis in S. mutans during acid adaptation.

One of the most interesting findings from the microarray analysis was that genes encoding multiple TCSs, including CiaHR, LevSR, LiaSR, ScnKR, Hk1037/Rr1038 and ComDE, were upregulated during acid adaptation of $S$. mutans. Using real-time qRT-PCR, we confirmed the same trend in the expression of these genes, including the genes encoding their cognate response regulators, in response to acidic $\mathrm{pH}$ (Table 2). In the $S$. mutans genome, there are 14 TCSs, and at least one orphan response regulator has been identified (Ajdic et al., 2002; Biswas et al., 2008; Idone et al., 2003). Some of these systems, such as LiaSR (formerly HK/ RR11), CiaHR, ComDE and CovR, have been found to play a role in acid resistance and considered as a major attribute to the virulence of S. mutans (Ahn et al., 2006; Idone et al., 2003; Li et al., 2001b, 2002; Lévesque et al., 2007; Kawada-Matsuo et al., 2009). However, little is known of the actual mechanisms of how these TCSs sense and integrate $\mathrm{pH}$ signals to regulate gene expression for acid adaptation. In B. subtilis and E. coli, many alternative sigma factors have been found to play major roles in regulating gene expression in response to various stresses, including acidic pH (Foster, 1995; Helmann, 2002). For example, at least 17 sigma factors have been identified in $B$. subtilis, seven of which are extracytoplasmic function sigma factors that play central regulatory roles in gene expression in response to stress (Haldenwang, 1995; Helmann, 2002). In the $S$. mutans genome, however, only two sigma factors, $\sigma^{70}$ and $\sigma^{\mathrm{X}}$, are identified and their roles in regulating acid adaptation is unclear (Ajdic et al., 2002). Thus, TCSs in $S$. mutans may play major roles in coordinating regulatory networks and gene expression in response to acid stress.

In addition to multiple TCSs, several genes encoding putative transcriptional regulators were upregulated, including sloR (SMU.186), rgg (SMU.1509), lacI (SMU.105), copY (SMU.424) and recX (SMU.1780). Their roles in acid adaptation are unclear. However, sloR is known to encode a metal-dependent transcriptional regulator involved in regulating the sloABCR operon for Mn and Fe uptake (Dunning et al., 2008). A recent study has linked the expression of the sloABCR operon to the acid stress response in S. mutans (Dunning et al., 2008; Idone et al., 2003). It is also known that $r g g$ encodes a transcriptional regulator in many Gram-positive bacteria, including S. mutans (Ajdic et al., 2002). Rgg coordinately regulates amino acid catabolism and virulence expression in Streptococcus pyogenes (Chaussee et al., 2003) and plays a role in the regulation of $g t f G$ that encodes glucosyltransferase in Streptococcus gordonii (Vickerman \& Minick, 2002). Presumably, the Rgg regulator in S. mutans may play a 
similar role in regulating an extracellular polysaccharide during acid adaptation.

\section{Downregulated genes}

The majority of the downregulated genes belong to six groups, including (i) transport and binding proteins $(n=19)$, (ii) energy metabolism $(n=18)$, (iii) cellular processes $(n=8)$, (iv) biosynthesis of proteins, amino acids and co-factors $(n=17),(\mathrm{v})$ nucleic acid metabolism $(n=6)$ and (vi) unknown or undesignated hypothetical proteins $(n=31)$. The general trend observed in the downregulated genes was that genes encoding products for transport, cellular processes and biosynthesis requiring higher energy levels were repressed at acidic pH (Supplementary Table S2). Possibly, S. mutans cells under acidic conditions might largely use energy to maintain internal $\mathrm{pH}$ homeostasis rather than for active energy-consuming processes and biosynthesis. For example, several genes, including SMU.670 (citB), SMU.671 (citZ) and SMU.672 (citC) that encode enzymes required for citrate metabolism in the Krebs cycle, were downregulated (Supplementary Table S2). Similarly, many genes encoding enzymes and transporters involved in the biosynthesis and transport of sugar were downregulated, including $p t s G$ that encodes the glucose-specific phosphoenolpyruvate-phosphotransferase system (PEP-PTS) (IIABC component). It is well known that bacterial PTSs are responsible for binding, transport and phosphorylation of numerous sugar substrates (Ajdic \& Pham, 2007; Ajdic et al., 2002). They play important roles in transporting specific sugars under sugar substrate limitation. These systems are also involved in the regulation of various metabolic and transcriptional processes. The downregulation of these genes might be a reflection of the cells' efforts to preserve energy at low $\mathrm{pH}$, particularly when a high concentration of sugar is still available in the culture.

Another interesting finding was that several late competence genes, comYA (SMU.1987), comYB (SMU.1985), comYD (SMU.1983), comEC (SMU.626) and comX (SMU.1997), were downregulated. To confirm these results, we examined two late competence genes, comYA and $\operatorname{comX}$ (Merritt et al., 2005), an early competence gene, comE, and its controlled bacteriocin-producing and immunity genes, $n \operatorname{lmC}$ (SMU.1914) and immA (SMU.1913), by real-time qRT-PCR. The results showed that, similar to the microarray data, $\operatorname{com} Y A$ and $\operatorname{com} X$ were indeed downregulated at $\mathrm{pH} 5.5$, but comE and the two bacteriocin-related genes were upregulated at this $\mathrm{pH}$ (Table 2). These results are surprising, since the ComCDE quorum sensing system in $S$. mutans is known to control both genetic competence and bacteriocin production ( $\mathrm{Li}$ et al., 2001a; van der Ploeg, 2005). One may expect the same impact when the ComCDE signal pathway is activated. This is true when CSP is added into a culture at neutral pH (Li et al., 2001a; Syvitski et al., 2007). In this case, however, the early and late competence genes were divergently regulated at low $\mathrm{pH}$. The mechanism involved in such divergent regulation is currently unclear. To further confirm the results, we assayed competence development for genetic transformation in two naturally transformable strains of S. mutans, UA159 and NG8, grown at either pH 5.5 or 7.5. The results showed almost no detectable transformation for the cells grown at $\mathrm{pH} 5.5$, regardless of use of CSP (Fig. 3). In contrast, the cells grown at $\mathrm{pH} 7.5$ had a normal transformation frequency $\left[10^{3}-10^{4}\right.$ transformants ( $\mu \mathrm{g}$ DNA $)^{-1} \mathrm{ml}^{-1}$, similar to that reported by $\mathrm{Li}$ et al. (2001a) and Syvitski et al. (2007). Addition of CSP at neutral $\mathrm{pH}$ could further increase the transformation frequencies of these two strains. The data suggest that acidic $\mathrm{pH}$ indeed inhibits competence development for genetic transformation. Since the early competence gene comE and its controlled bacteriocin-related genes were not affected at $\mathrm{pH} 5.5$, we assume that acidic $\mathrm{pH}$ most probably inhibits competence development by suppressing the late competence genes, such as $\operatorname{com} X$ and $\operatorname{com} Y A$. It is well known that ComE is a key regulator in coupling CSPdependent genetic competence and bacteriocin production in S. mutans (Li et al., 2001a; Kreth et al., 2007). However, there appears to be a lack of evidence that ComE in $S$. mutants directly interacts with $\operatorname{com} X$, which directs transcription of late competence genes, as there is no ComE binding site at the promoter site of $\operatorname{com} X$ (Martin et al., 2006). Thus, our data appear to favour the model of Burne and colleagues, who have proposed that competence development is hierarchically regulated both via CSPdependent and CSP-independent circuits involving two signalling systems, ComCDE and CiaHR (Ahn et al., 2006). The evidence from our study suggests that $S$. mutans may divergently regulate the early and late competence genes through different pathways in response to different signals.

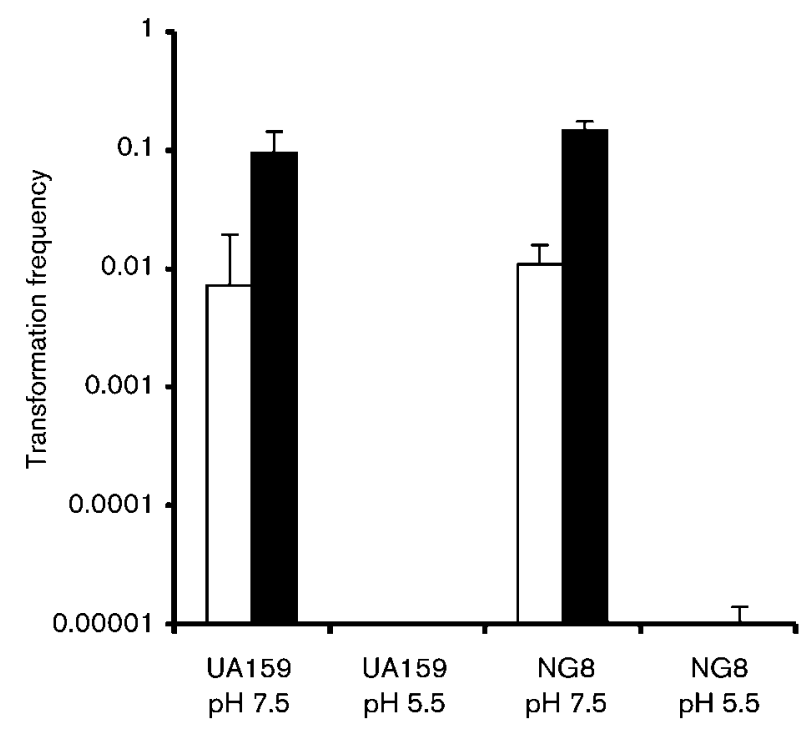

Fig. 3. Development of genetic competence in S. mutans UA159 at $\mathrm{pH} 7.5$ and 5.5 with ( $\mathbf{\square})$ or without $(\square)$ the addition of CSP. 
Acidic $\mathrm{pH}$ is a significant factor that may directly or indirectly affect one of these signal transduction pathways. Clearly, further work is required to study the mechanism of how these genes are divergently regulated.

\section{Effect of inactivation of the histidine kinases (HK) on ATR}

To determine if TCSs might play a role in ATR of $S$. mutans, we constructed gene deletion mutants defective in histidine kinase sensor proteins $\mathrm{CiaH}$, LevS, LiaS, ScnK and HK1037 of individual systems by using an allelic replacement strategy involving PCR-ligation mutagenesis (Lau et al., 2002). All the mutants were genetically confirmed (Supplementary Fig. S1) and examined for their growth kinetics in TYG broth at pH 5.5 and 7.5. The results showed that all the mutants grew similarly to the parent UA159 at pH 7.5 (data not shown). The growth yields of these mutants, except SmlevS that had slightly higher yield, were almost the same as that of the parent after $16 \mathrm{~h}$ growth. However, all the mutants, particularly SmliaS, SmciaH and Sm1037, at pH 5.5 were retarded in their growth compared to the parent UA159 (Fig. 4). These results suggest that inactivation of each of these systems results in a mutant that has a reduced growth rate at acidic $\mathrm{pH}$. Recent studies have shown that several TCS have been involved in acid resistance in S. mutans (Ahn et al., 2006; Biswas et al., 2008; Li et al., 2002; Lévesque et al., 2007; Kawada-Matsuo et al., 2009). Some of the TCS identified to be involved in acid tolerance in these studies appear to be different from those in our study, probably owing to the differences in the strains, mutant construction, growth

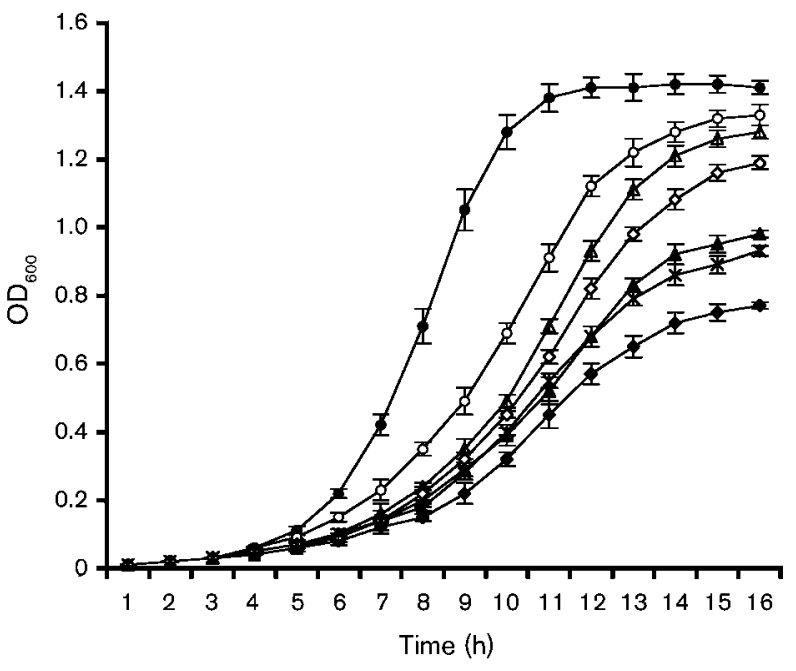

Fig. 4. Growth kinetics of the $S$. mutans mutants grown at $\mathrm{pH} 5.5$ and the parent UA159 grown at $\mathrm{pH} 5.5$ and 7.5. U, UA159 (pH 7.5); ○, UA159 (pH 5.5); $\mathbf{\Delta}$, SmciaH (pH 5.5); $\triangle$, SmlevS $(\mathrm{pH} 5.5) ; \diamond$, SmliaS; (pH 5.5); $\diamond, \quad$ SmscnK (pH 5.5); $\times$, Smhk1037 (pH 5.5). conditions and assay methods. To further determine the roles of these TCS in inducible ATR, in which pre-exposure of $S$. mutans to $\mathrm{pH} 5.5$ for $2 \mathrm{~h}$ (adaptation) would render the organism less susceptible to a subsequent lethal acid exposure (Svensäter et al., 1997), we examined inducible ATR of these mutants. The results showed that all the mutants were also impaired in exponential-phase ATR, since pre-exposure of these mutants to $\mathrm{pH} 5.5$ for $2 \mathrm{~h}$ did not significantly enhance the protection of the strains from being killed at pH 3.5 (Fig. $5 \mathrm{a}$ and b). In contrast, the parent strain showed a 30 -fold higher level of survival at $\mathrm{pH} 3.5$ after the cells were adapted to $\mathrm{pH}$ 5.5. The evidence from this study clearly shows that these TCSs are required

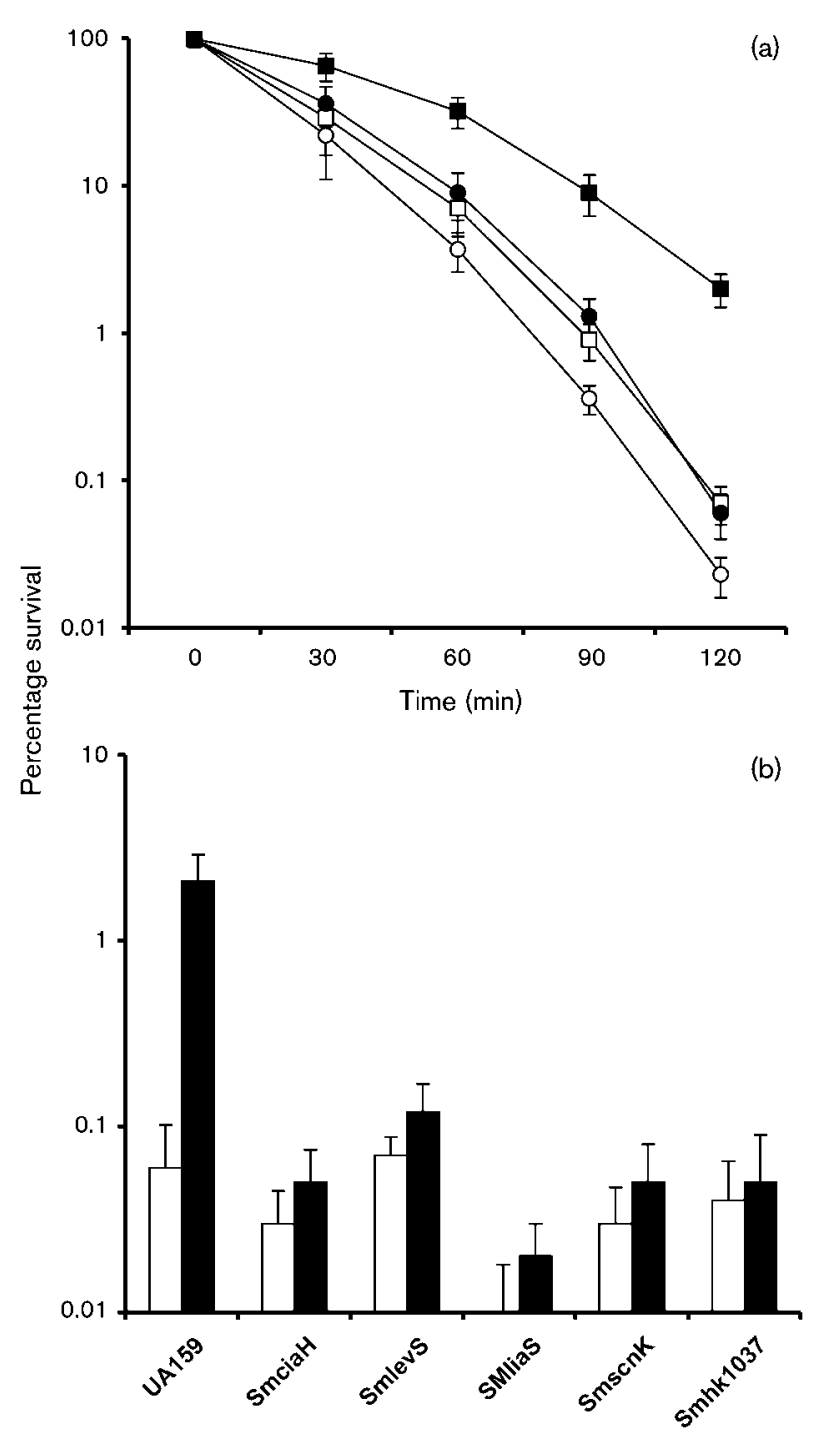

Fig. 5. ATR of $S$. mutans strains. (a) Survival kinetics of acidadapted $(\mathbf{\square}, \boldsymbol{\bullet})$ or non-adapted $(\square, \bigcirc)$ cells of S. mutans UA159 $(\boldsymbol{\square}, \square)$ and SmciaH $(\bullet, \bigcirc)$ following exposure to $\mathrm{pH}$ 3.5. (b) Percentage survival of acid-adapted ( $\boldsymbol{\square}$ ) or non-adapted $(\square)$ cells of all the mutants and parent strain UA159 following exposure to $\mathrm{pH} 3.5$ for $2 \mathrm{~h}$. 
for $S$. mutans to sense and integrate acidic $\mathrm{pH}$ signals for optimal induction of acid adaptation.

\section{Effect of inactivation of histidine sensor kinases (HK) on acid production}

In addition to ATR, we examined acid production of these mutants and found that all the mutants, particularly SmliaS and $\mathrm{SmciaH}$, had reduced glycolytic $\mathrm{pH}$ drop rates than the parent strain (Fig. 6). The differences, albeit subtle, could be observed between the first $10-20 \mathrm{~min}$ immediately following the glucose pulse. Also, the final $\mathrm{pH}$ levels of all the mutants were slightly higher than the parent strain. If the acid was neutralized, glycolysis in the cultures took place again, indicating that glycolytic activity had ceased due to inhibition by the lower $\mathrm{pH}$, and not by glucose depletion. The data further supported that these mutants were more sensitive to acidic $\mathrm{pH}$ than the parent.

\section{Competitive fitness analysis}

To assess the fitness of the mutants grown at acidic $\mathrm{pH}$, we established dual-strain mixed cultures in a chemostat for $\mathrm{CI}$ analysis by inoculating a 1:1 ratio of a mutant and the parent strain UA159. Continuous chemostat culture is considered to be particularly advantageous for studying the effects of environmental factors on bacterial growth, because a chemostat culture allows good control of the growth-limiting substrate, growth rate, $\mathrm{pH}$ and other growth parameters (Li et al., 2001a, b). By controlling these parameters, one can effectively minimize the variations often encountered in batch cultures and reproduce the data

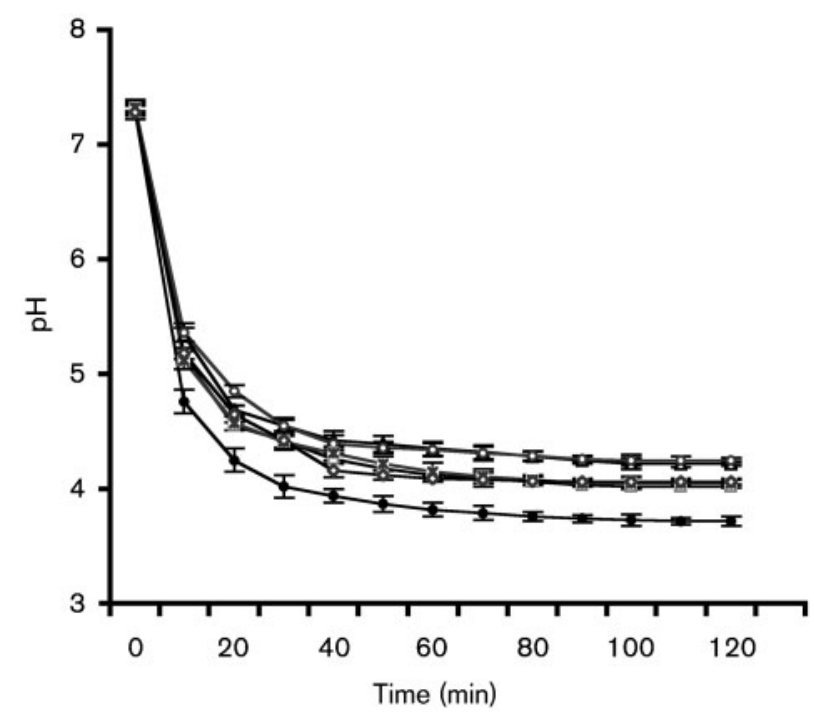

Fig. 6. Glycolytic pH drop assay of the $S$. mutans histidine sensor kinase mutants. All the mutants showed slower glycolytic $\mathrm{pH}$ drop rates than UA159 during the first half hour following the glucose pulse. ๑, UA159; $\triangle$, SmciaH; $\square$, SmlevS; $\bigcirc$, SmliaS; $\times$, SmscnK; $\diamond$, Smhk1037. observed in the chemostat. Our results revealed that at neutral $\mathrm{pH}(\mathrm{pH} 7.5 \pm 0.2)$, all the mutants, except SmliaS, maintained a stable co-culture with the parent population under steady-state chemostat conditions (Fig. 7a, b). There was no significant difference in the CI values between the samples at the end of day 5 and the initial inocula. The results suggested that all the mutants, except SmliaS, grew equally well in the chemostat at neutral $\mathrm{pH}$ at a low dilution rate $\left(D=0.1 \mathrm{~h}^{-1}\right)$. In contrast, the numbers of the mutant cells dramatically decreased in the co-cultures without $\mathrm{pH}$ control ( $\mathrm{pH}$ ranging from 5.0-4.6), resulting in a 1.5-2.0 magnitude decrease in the CI values $(P<0.01$ or
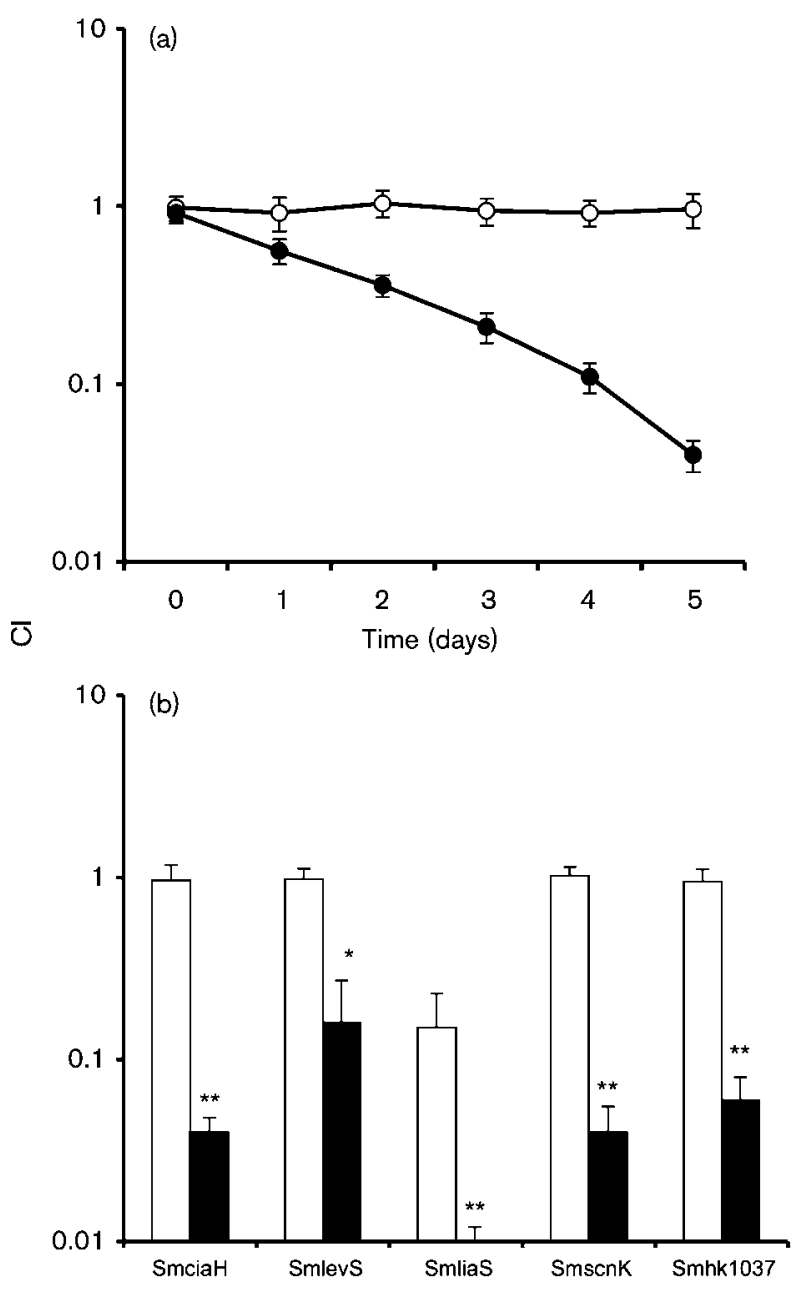

Fig. 7. $\mathrm{A} \mathrm{Cl}$ analysis of the $S$. mutans mutants versus parent UA159 in dual-strain mixed cultures. Each culture was initiated by inoculating a $1: 1$ ratio of a mutant and the parent. (a) An example of the time-course $\mathrm{Cl}$ analysis of SmciaH versus UA159 grown in a chemostat at either $\mathrm{pH} 7.5$ or at an acidic $\mathrm{pH}$ ranging from 4.6 to 5.2. $\bigcirc$, pH control; $\bullet$, no $\mathrm{pH}$ control. (b) Final $\mathrm{Cl}$ values of five pairs of dual-strain cultures grown at either $\mathrm{pH} 7.5$ or at acidic $\mathrm{pH} 4.6-5.2$ after 5 days of continuous culture. ${ }^{*}, P \leqslant 0.05$; ${ }^{* *}$, $P \leqslant 0.01$ in the $\mathrm{Cl}$ values between $\mathrm{pH}$ control $(\square)$ and no $\mathrm{pH}$ control (ם). 
0.05 ) between the samples at the end of day 5 and the time when the $\mathrm{pH}$ controller was disconnected. Clearly, these mutants were less competitive than the parent for persistence in co-cultures at acidic $\mathrm{pH}$, suggesting that the mutants had reduced fitness to maintain their population sizes at lower $\mathrm{pH}$ levels. Taken together, the data from this study support the notion that multiple TCSs in S. mutans play regulatory roles in acid production, sensing and adaptation. Further study is necessary to characterize how these TCSs sense acidic $\mathrm{pH}$ signals to activate the regulatory networks for acid adaptation.

\section{Concluding remarks}

Acidic $\mathrm{pH}$ represents a critical environmental constraint for all macromolecular structures, physiological activities and energy conversions in bacteria. Accordingly, the ability to sense, respond and adapt to $\mathrm{pH}$ changes represents a critical regulatory module that interconnects with many components of cellular processes and is essential for all organisms. S. mutans in dental biofilms is exposed to cycles of $\mathrm{pH}$ fluctuation during carbohydrate consumption. The gene expression and physiological activities of this organism can be profoundly influenced by its capacity to adapt to dynamic environmental changes. The results presented herein indicate that $\mathrm{pH}$ is an important environmental signal that induces genome-wide transcriptional changes in $S$. mutans. Considering the large number of genes discovered to be $\mathrm{pH}$-regulated in bacteria, the actual mechanism responsible for sensing and integrating $\mathrm{H}^{+}$signals for acid adaptation is poorly understood. The evidence from this study suggests that multiple TCSs are involved in sensing and transducing the $\mathrm{pH}$ signal by $S$. mutans to coordinate its regulatory networks and gene expression for enhanced adaptation to acidic $\mathrm{pH}$. Analysis of these signal transduction systems in $\mathrm{pH}$ sensing, response and regulation of specific gene products will shed light on the molecular mechanism by which $S$. mutans adapts to acidic $\mathrm{pH}$ in dental biofilms. In addition, large numbers of genes encoding hypothetical proteins of unknown function, which display either increased or decreased expression during acid adaptation, appear to be interesting, as they may be important in ATR of $S$. mutans. Thus, continued analysis of these gene products in acid adaptation and their regulatory mechanisms is clearly needed.

\section{ACKNOWLEDGEMENTS}

We thank Dr Laura Brown and Jason William at the Institute for Marine Biosciences, National Research Council of Canada (NRC), for the access to the microarray scanner and technical assistance. We also thank the Pathogen Functional Genomics Resource Center (PFGRC) at the J. Craig Venter Institute for the S. mutans microarray slides. This work was supported by Grant MOP-74487 from the Canadian Institutes for Health Research. Y.-H. L. was a recipient of the Nova Scotia-CIHR Regional Partnership Program New Investigator Award. T.S. was a recipient of the CIHR Northern Program Summer Studentship.

\section{REFERENCES}

Ahn, S. J., Wen, Z. T. \& Burne, R. A. (2006). Multilevel control of competence development and stress tolerance in Streptococcus mutans UA159. Infect Immun 74, 1631-1642.

Ajdic, D. \& Pham, V. T. (2007). Global transcriptional analysis of Streptococcus mutans sugar transporters using microarrays. J Bacteriol 189, 5049-5059.

Ajdic, D., McShan, W. M., McLaughlin, R. E., Savic, G., Chang, J., Carson, M. B., Primeaux, C., Tian, R., Kenton, S. \& other authors (2002). Genome sequence of Streptococcus mutans UA159, a cariogenic dental pathogen. Proc Natl Acad Sci U S A 99, 1443414439 .

Bender, G. R., Sutton, S. V. \& Marquis, R. E. (1986). Acid tolerance, proton permeabilities, and membrane ATPases of oral streptococci. Infect Immun 53, 331-338.

Biswas, I., Drake, L., Erkina, D. \& Biswas, S. (2008). Involvement of sensor kinases in the stress tolerance response of Streptococcus mutans. J Bacteriol 190, 68-77.

Burne, R. A., Quivey, R. G., Jr \& Marquis, R. E. (1999). Physiologic homeostasis and stress responses in oral biofilms. Methods Enzymol 310, 441-460.

Chaussee, M. S., Somerville, G. A., Reitzer, L. \& Musser, J. M. (2003). Rgg coordinates virulence factor synthesis and metabolism in Streptococcus pyogenes. J Bacteriol 185, 6016-6024.

Cotter, P. D. \& Hill, C. (2003). Surviving the acid test: responses of Gram-positive bacteria to low pH. Microbiol Mol Biol Rev 67, 429453.

Dunning, D. W., McCall, L. W., Powell, W. F., Jr, Arscott, W. T., McConocha, E. M., McClurg, C. J., Goodman, S. D. \& Spatafora, G. A. (2008). SloR modulation of the Streptococcus mutans acid tolerance response involves the GcrR response regulator as an essential intermediary. Microbiology 154, 1132-1143.

Foster, J. W. (1995). Low $\mathrm{pH}$ adaptation and the acid tolerance response of Salmonella typhimurium. Crit Rev Microbiol 21, 215-237.

Fozo, E. M., Scott-Anne, K., Koo, H. \& Quivery, R. G., Jr (2007). Role of unsaturated fatty acid biosynthesis in virulence of Streptococcus mutans. Infect Immun 75, 1537-1539.

Griswold, A. R., Jameson-Lee, M. \& Burne, R. A. (2006). Regulation and physiologic significance of the agmatine deiminase system of Streptococcus mutans UA159. J Bacteriol 188, 834-841.

Hahn, K., Faustoferri, R. C. \& Quivey, R. G., Jr (1999). Induction of an AP endonuclease activity in Streptococcus mutans during growth at low pH. Mol Microbiol 31, 1489-1498.

Haldenwang, W. G. (1995). The sigma factors of Bacillus subtilis. Microbiol Rev 59, 1-30.

Hamilton, I. R. \& Svensäter, G. (1998). Acid-regulated proteins induced by Streptococcus mutans and other oral bacteria during acid shock. Oral Microbiol Immunol 13, 292-300.

Hanna, M. N., Ferguson, R. J., Li, Y.-H. \& Cvitkovitch, D. G. (2001). $u v r A$ is an acid-inducible gene involved in the adaptive response to low pH in Streptococcus mutans. J Bacteriol 183, 5964-5973.

Hasona, A., Zuobi-Hasona, K., Crowley, P. J., Abranches, J., Ruelf, M. A., Bleiweis, A. S. \& Brady, L. J. (2007). Membrane composition changes and physiological adaptation by Streptococcus mutans signal recognition particle pathway mutants. J Bacteriol 189, 1219-1230.

Helmann, J. D. (2002). The extracytoplasmic function (ECF) sigma factors. Adv Microb Physiol 46, 47-110.

Idone, V., Brendtro, S., Gillespie, R., Kocaj, S., Peterson, E., Rendi, M., Warren, W., Michalek, S., Krastel, K. \& other authors (2003). Effect of 
an orphan response regulator on Streptococcus mutans sucrosedependent adherence and cariogenesis. Infect Immun 71, 4351-4360.

Kakinuma, Y. (1998). Inorganic cation transport and energy transduction in Enterococcus hirae and other streptococci. Microbiol Mol Biol Rev 62, 1021-1045.

Kawada-Matsuo, M., Shbata, Y. \& Yamashita, Y. (2009). Role of two component signaling response regulators in acid tolerance of Streptococcus mutans. Oral Microbiol Immunol 24, 173-176.

Kreth, J., Hung, D. C. I., Merritt, J., Perry, J., Zhu, L., Goodman, S. D., Cvitkovitch, D. G., Shi, W. \& Qi, F. (2007). The response regulator ComE in Streptococcus mutans functions both as a transcription activator of mutacin production and repressor of CSP biosynthesis. Microbiology 153, 1799-1807.

Kuhnert, W. L., Zheng, G., Roberta, C., Faustoferri, R. C. \& Quivey, R. G., Jr (2004). The F-ATPase operon promoter of Streptococcus mutans is transcriptionally regulated in response to external $\mathrm{pH}$. J Bacteriol 186, 8524-8528.

Kuramitsu, H. K., He, X., Lux, R., Anderson, M. H. \& Shi, W. (2007). Interspecies interactions within oral microbial communities. Microbiol Mol Biol Rev 71, 653-670.

Lau, P. C., Sung, C. K., Lee, J. H., Morrison, D. A. \& Cvitkovitch, D. G. (2002). PCR ligation mutagenesis in transformable streptococci: application and efficiency. J Microbiol Methods 49, 193-205.

Lemos, J. A. \& Burne, R. A. (2008). A model of efficiency: stress tolerance by Streptococcus mutans. Microbiology 154, 3247-3255.

Lemos, J. A., Abtanches, J. \& Burne, R. A. (2005). Responses of cariogenic streptococci to environmental stresses. Curr Issues Mol Biol 7, 95-108.

Len, A. C., Harty, D. W. \& Jacques, N. A. (2004). Stress-responsive proteins are upregulated in Streptococcus mutans during acid tolerance. Microbiology 150, 1339-1351.

Lévesque, C. M., Mair, R. W., Perry, J. A., Lau, P. C. Y., Li, Y.-H. \& Cvitkovitch, D. G. (2007). Systemic inactivation and phenotypic characterization of two-component systems in expression of Streptococcus mutans virulence properties. Lett Appl Microbiol 45, 398-404.

Li, Y.-H., Lau, P. C. Y., Lee, J. H., Ellen, R. P. \& Cvitkovitch, D. G. (2001a). Natural genetic transformation of Streptococcus mutans growing in biofilms. J Bacteriol 183, 897-908.

Li, Y.-H., Hanna, M. N., Svensäter, G., Ellen, R. P. \& Cvitkovitch, D. G. (2001b). Cell density modulates acid adaptation in Streptococcus mutans: implication for survival in biofilms. J Bacteriol 183, 68756884.

Li, Y.-H., Lau, P. C. Y., Tang, N., Svensäter, G., Ellen, R. P. \& Cvitkovitch, D. G. (2002). Novel two-component regulatory system involved in biofilm formation and acid resistance in Streptococcus mutans. J Bacteriol 184, 6333-6342.
Li, Y.-H., Tian, X.-L., Layton, G., Norgaard, C. \& Sisson, G. (2008). Additive attenuation of virulence and cariogenic potential of Streptococcus mutans by simultaneous inactivation of the ComCDE quorum sensing system and HK/RR11 two-component regulatory system. Microbiology 154, 3256-3265.

Magalhaes, P. P., Paulino, T. P., Thedei, G., Jr \& Ciancaglini, P. (2005). Kinetic characterization of P-type membrane ATPase from Streptococcus mutans. Comp Biochem Physiol B Biochem Mol Biol 140, 589-597.

Marsh, P. D. (1994). Microbial ecology of dental plaque and its significance in health and disease. Adv Dent Res 8, 263-271.

Martin, B., Quentin, Y., Fichant, G. \& Claverys, J.-P. (2006). Independent evolution of competence regulatory cascades in streptococci? Trends Microbiol 14, 339-345.

Martin-Galiano, A. J., Ferrandiz, M. J. \& de la Campa, A. G. (2001). The promoter of the operon encoding the $\mathrm{F}_{0} \mathrm{~F}_{1}$ ATPase of Streptococcus pneumoniae is inducible by $\mathrm{pH}$. Mol Microbiol 41, 1327-1338.

Merritt, J., Qi, F. \& Shi, W. (2005). A unique nine-gene $\operatorname{com} Y$ operon in Streptococcus mutans. Microbiology 151, 157-166.

Nascimento, M. M., Lemos, J. A., Abranches, J., Gonçalves, R. B. \& Burne, R. A. (2004). Adaptive acid tolerance response of Streptococcus sobrinus. J Bacteriol 186, 6383-6390.

Quivey, R. G., Jr, Kuhnert, W. L. \& Hahn, K. (2001). Genetics of acid adaptation in oral streptococci. Crit Rev Oral Biol Med 12, 301-314.

Svensäter, G., Larsson, U. B., Greif, E. C., Cvitkovitch, D. G. \& Hamilton, I. R. (1997). Acid tolerance response and survival by oral bacteria. Oral Microbiol Immunol 12, 266-273.

Syvitski, R. T., Tian, X.-L., Sampara, K., Salman, A., Lee, S. F., Jakeman, D. L. \& Li, Y.-H. (2007). Structure-activity analysis of quorum sensing signaling peptides from Streptococcus mutans. J Bacteriol 189, 1441-1450.

van der Ploeg, J. R. (2005). Regulation of bacteriocin production in Streptococcus mutans by the quorum-sensing system required for development of genetic competence. J Bacteriol 187, 3980-3989.

Vats, N. \& Lee, S. F. (2001). Characterization of a copper-transport operon, copYAZ, from Streptococcus mutans. Microbiology 147, 653662.

Vickerman, M. M. \& Minick, P. E. (2002). Genetic analysis of the rgg$g t f G$ junctional region and its role in Streptococcus gordonii glucosyltransferase activity. Infect Immun 70, 1703-1714.

Wilkins, J. C., Homer, K. A. \& Beighton, D. (2002). Analysis of Streptococcus mutans proteins modulated by culture under acidic conditions. Appl Environ Microbiol 68, 2382-2390.

Edited by: M. Kilian 